\title{
Kansallisen historian ja kulttuuriperinnön uudelleenarviointia 10-vuotisjuhlaseminaarissa
}

Monen tieteen paikka - Tutkimus, metodit ja SKS, 14.-15.5.2019 Helsinki.

\author{
Eeva-Liisa Bastman
}

\begin{abstract}
$\mathrm{K}$ ymmenen vuotta sitten Suomalaisen Kirjallisuuden Seuraan perustettiin tutkimusosasto, joka sittemmin on kehittynyt noin kolmenkymmenen tutkijan vireäksi, monitieteiseksi yksiköksi. SKS:n projekteissa toimivien työntekijöiden lisäksi osastolla työskentelee tätä nykyä myös omalla rahoituksella työskenteleviä apurahatutkijoita. Tutkimusaloista edustettuina ovat historiantutkimus, folkloristiikka, kirjallisuudentutkimus, taidehistoria ja musiikintutkimus.
\end{abstract}

Tutkimusosaston kymmenvuotisjuhlien kunniaksi järjestettiin Monen tieteen paikka - Tutkimus, metodit ja SKS -juhlaseminaari Helsingissä 14.-15.5.2019. Juhlakollokviossa kuultiin esitelmiä sekä tutkimusosaston nykyisiltä ja entisiltä edustajilta että muilta eri yliopistoissa ja tutkimuslaitoksissa toimivilta tutkijoilta, jotka tekevät tutkimusta SKS:n aineistoista tai SKS:n keskeisalojen piirissä.

Kaksipäiväisen seminaarin aikana kuultiin parisenkymmentä esitelmää sekä Lotte Tarkan pitämä keynote-luento. Esitelmissä SKS:n keskeisaloja koskevan tutkimuksen aineistollinen ja metodologinen runsaus näyttäytyi koko runsaudessaan. Samalla monissa esitelmissä korostuivat yhteiset teemat ja kysymyksenasettelut, jotka liittyvät etenkin kansallisen kulttuuriperinnön ja siihen liittyvien käsitteiden uudelleenarviointiin tutkimuksen välinein.

\section{Suullisen ja kirjallisen suhde}

Avauspuheenvuorossaan seuran pääsihteeri Tuomas M. S. Lehtonen muistutti seuran tarkoituksesta ja tehtävästä: säilyttää, harjoittaa ja edistää kielen, kansanperinteen ja kirjallisuuden tutkimusta Suomessa. SKS:n arkistokokoelmat ja toiminnan perusajatus kytkeytyvät prosessiin, jossa suullisesta ja paikallisesta kulttuurista muokattiin kirjallista ja se siirrettiin kansallisen ideologian keskiöön. Näiden prosessien ja niihin liittyvän vallankäytön kriittinen tarkastelu on myös tämän päivän tutkimusosaston toiminnan ytimessä. Yhtenä keskeisenä aiheena on ollut kirjallisen ja suullisen kulttuurin välinen dynamiikka, lainaamisen ja 
omimisen käytänteet, sekä kysymykset siitä mitä on kansan kulttuuri tai kansallinen kulttuuri, miten sitä luodaan ja mihin tarkoituksiin sitä käytetään.

Esitelmissä lähtökohtia kulttuuriperinnön uudelleenarviointiin tarjosivat muun muassa perinteen tekijöihin, tekijyyden luonteeseen sekä yksilön ja kollektiivin suhteisiin liittyvät kysymykset. Esimerkiksi Seppo Knuuttila tarkasteli esitelmässään sitä, miten folkloristiikan subjektikäsitys on muuttunut anonyymistä kansasta nimettyjen henkilöiden yksilöllisen repertuaarin analyysiin. Anna Kuismin puhui kirjoittavista kansanihmisistä ja räätälin vaimo Mathilda Grönqvististä (1863-1903), jonka SKS:Ile lähettämät kirjeet tuovat esiin rahvaan näkökulman vuosisadan vaihteen epävakaisiin vuosiin ja kokemuksiin maalaisväestön kahtiajakautuneisuudesta. Samassa sessiossa taidehistorioitsija Katri Vuola esitelmöi keskiajan puuveistosten attribuointikysymyksistä. Vuolan mukaan Liedon mestarin kaltaiset fiktiiviset persoonat toimivat keinona pyrittäessä luomaan ymmärrystä ja kiinnostusta keskiajan taidetta kohtaan. Vuolan esitelmä tarjosi myös esimerkin siitä, miten fiktiiviset tekijäpersoonat toimivat yhä edelleen tutkimuksen popularisoinnissa, vaikka tiede on niistä luopunut.

Aineistot ja niiden käyttö toimivat lähtökohtana sessiossa Teksti, arkisto ja kritiikki. Esitelmissään Sakari Katajamäki, Niina Hämäläinen ja Veijo Pulkkinen käsittelivät arkistoaineistojen kuten käsikirjoitusten, päiväkirjojen sekä tallennetun perinneaineiston suhdetta näiden pohjalta tuotettuihin teoksiin - Kalevalaan, Aleksis Kiven tuotantoon sekä Juha Mannerkorven päiväkirjaromaaniin - ja erilaisia tapoja tarkastella tätä suhdetta.

SKS:n keskeisalojen uusista tutkimussuuntauksista esillä olivat muun muassa tekstuaalitieteet, jota on Suomessa kehitetty pitkälti juuri tutkimusosastolla Aleksis Kiven teosten kriittisten editioiden julkaisua varten. Ulla Savolaisen esitelmä puolestaan esitteli muistitietotutkimusta ja sen kytköstä vernakulaarin käsitteen vakiintumiseen. Savolaisen tapaustutkimus liittyi internointeihin Suomessa 1944-1946, ja se valotti kiinnostavalla tavalla materiaalisuuden ja esineiden merkitystä muistelun prosesseissa.

\section{Digitaalisuus ja eksklusiivisuus}

Digitaalisia metodeja sivuttiin useissa esityksissä. Keskeisessä roolissa digitaaliset analyysivälineet olivat esimerkiksi Heikki Kokon esitelmässä, joka esitteli lehdistön lukijakirjeitä ja niiden yhteiskunnallisia vaikutuksia koskevaa tutkimusta. Translocalis-tietokantaan on tarkoitus tallentaa kaikki 1800-luvun jälkipuoliskon lukijakirjeet, joita on kaikkiaan lähes 20000. Laajojen aineistojen käsittelystä on kyse myös Petri Karosen varhaisen uuden ajan historiografiaa käsittelevässä tutkimusprojektissa, jossa käytetään verkostonanalyysityökaluja ja niiden avulla tehtyjä visualisointeja. Näiden työkalujen hyödyntämisestä antoi esimerkin myös Ilona Pikkanen historiakulttuuria käsittelevässä esitelmässä, jossa 1800-luvulta peräisin olevia historiallisia näytelmiä luettiin digitaalisin menetelmin tuotettua tietoa apuna käyttäen ja määrällisiä ja laadullisia metodeja yhdistäen.

Monissa esitelmissä problematisoitiin erilaisia tieteen tai kansallisen ideologian nimissä tehtyjä rajanvetoja. Tällaisia ovat esimerkiksi suullisen ja kirjallisen kulttuurin rajapinnat ja kansan ja eliitin erottaminen sekä kielten, kansallisuuksien ja valtioiden rajat. Kansallisten rajojen ylittämistä tarkasteltiin 1800-luvulta lähimenneisyyteen: esimerkiksi Kirsi Keravuoren esitelmä käsitteli karanneita merimiehiä siirtolaisuuden pioneereina, Mehdi Ghasemi 
siirtolaisnaisten henkilöhahmoja amerikansuomalaisissa romaaneissa ja Johanna Leinonen eri kansallisuuksien välisiä parisuhteita ja niistä tehtyjä lehtijuttuja 1980- ja 1990-luvulla.

Rajanveto meihin ja muihin liittyy myös kysymykseen kansan määrittelystä ja sen myötä siitä, kenen aineistosta muistitieto-organisaatioissa ollaan kiinnostuneita ja kenen perinnettä tallennetaan. Kati Mikkolan lähtökohtana olivat SKS:n arkiston perinneaineistot ja se, miten erilaiset vähemmistöt ovat edustettuina arkistoaineistoissa. Mikkolan mukaan vähemmistöjen aineistoja on vaihdellen joko sisällytetty osaksi suomalaista perinnettä tai suljettu ulos. Tutkimuksen muuttuvat näkökulmat ja keruupolitiikan muutokset näkyvät siinä, mitä aineistoa kulloinkin on kerätty ja miten vähemmistöjen aineistoon on suhtauduttu. Painopiste on yhä enemmän siirtynyt aidon suomalaisen kulttuurin dokumentoinnista koko kulttuurisen kirjon tallentamiseen.

Monissa esityksissä käsiteltiin tutkimuksessa tapahtunutta muutosta suhteessa "kansaan" oman kulttuurinsa tekijöinä ja toimijoina, sekä sitä, miten muutos heijastuu tutkimusaineistoihin ja metodeihin. Tätä paradigman muutosta havainnollisti Lotte Tarkan keynote -luento Rajatapaus - suullis-kirjallinen tragedia viimeisen runonlaulajan synnystä erinomaisen kiinnostavalla tavalla. Tarkan aiheena oli runonlaulaja ja tietäjä Riiko Kallio (1896-1942), jonka toimintaa ja vaiheita käsiteltiin Vienan Karjalan 1900-luvun alun poliittisia murroksia vasten. Kallio yritti luovia muuttuvien poliittisten realiteettien keskellä toimimalla yhteistyössä sekä Suomen että myöhemmin neuvostoviranomaisten kanssa, ja vaihtoi nimeä ja identiteettiä tilaisuuden niin vaatiessa. Suhtautumista häneltä tallennettuihin runoihin on leimannut folkloristiikan ongelmallinen käsitys autenttisuudesta ja puhtaan suullisuuden ideaali: runoja on pidetty Kalevalan epäaitona jälkilaulantana, väärennöksinä. Toisesta näkökulmasta ne tarjoavat näkymiä kirjallisen ja suullisen perinteen välillä tapahtuviin välittämisen ja omaksumisen prosesseihin. Tarkan sanoin suullisen ja kirjallisen rajanpinta on "dynaaminen ja läpäisevä - se välitti, ei jakanut".

Juhlaseminaarin päätteeksi Tiina Onikki-Rantajääskö kiteytti kahden tiiviin esitelmäpäivän annin loppupuheenvuorossaan. Puheenvuorossa nostettiin esiin uusien tulkintojen ja uudelleenarviointien merkitys ja korostettiin sitä, miten Suomalaisen Kirjallisuuden Seuraan kytkeytyvä tutkimus uusintaa käsitystä suomalaisesta kulttuurista etsiessään uusia näkökulmia kanonisoituneisiin aineistoihin ja tulkintatraditioihin. Tätä tutkimusta tehdään, kuten juhlaseminaarin esitelmistä oli nähtävissä, laajalla rintamalla, monitieteisesti, ja läheisessä yhteistyössä eri yliopistojen kanssa.

FT Eeva-Liisa Bastman toimii tutkijana Suomen akatemian rahoittamassa hankkeessa Laulut ja kirjoitukset: uskon ja ilmaisun rekisterit varhaismodernissa Pohjolassa, jossa hän tutkii suomenkielistä runoutta 1600- ja 1700-luvulla. 